\title{
PANDANGAN AGAMA-AGAMA TERHADAP SILA PERTAMA PANCASILA
}

\author{
Arthur Aritonang \\ Sekolah Tinggi Teologi Cipanas \\ Jl. Gadog I/ 36 Cipanas, Cianjur, Jawa Barat 43253 \\ Email:arthur.sttcipanas@yahoo.co.id
}

\begin{abstract}
ABSTRAK: Penelitian ini didorong oleh persoalan yang memperlihatkan semakin menipisnya toleransi dalam relasi umat beragama di Indonesia. Padahal bangsa Indonesia adalah bangsa yang beragama serta mengakui sila pertama Pancasila berserta dengan maknanya, sehingga idealnya keharmonisan hubungan antar pemeluk agama bisa terlihat di ruang publik. Namun kenyataannya gerakan intoleran radikal yang selalu bergerak dengan mengatasnamakan agama, membuat bangsa Indonesia mengalami ancaman disintegrasi. Apakah dalam hal ini agama-agama di Indonesia menolak makna dari sila pertama Pancasila? Lantas, bagaimana pandangan iman Kristen terhadap makna sila pertama Pancasila? Melalui metode kepustakaan penelitian ini menemukan bahwa (1) agama tidaklah salah melainkan cara memahami dan menginterpretasi teks suci yang ditafsirkan sesuai dengan kepentingan kelompok agamanya; (2) iman Kristen meyakini bahwa sila pertama Pancasila mengandung nilai-nilai firman Allah.
\end{abstract}

Kata Kunci: ketuhanan yang maha esa; agama-agama; kerukunan umat beragama; iman kristen; pancasila

\section{THE VIEWS OF RELIGIONS ON THE FRIST PRINCIPLE OF PANCASILA}

\begin{abstract}
This research is driven by the problem of dwindling tolerance in religious relations in Indonesia. Indonesian is a religious country and recognizes the first principle of Pancasila along with its meaning, so ideally harmonious relationship between religions can be seen in the public sphere. However, the fact is that the intolerant, radical movement, which always moves in the name of religion, makes Indonesia to be threatened by disintegration. In this case, do the religions in Indonesia reject the meaning of the first principle of Pancasila? And what is the Christian faith's view on the meaning of the first principle of Pancasila? Through literature method, this research finds that (1) the fault is not in religion, rather in the way to understand and interpret the holy text, which is read according to the interests of the religious group; (2) Christian faith believes that the first principles of Pancasila contain the values of the Word of God.
\end{abstract}

Keywords: the beliefe in one god; religions; religious harmony; christian faib; pancasila 


\section{PENDAHULUAN}

Membahas mengenai sila pertama Pancasila dalam tulisan ilmiah selalu menarik perhatian di masa sesudah Orde Baru. Meskipun sudah banyak tulisan yang mengkaji mengenai sila pertama Pancasila. Namun yang membedakan tulisan ini dari tulisan pada umumnya ialah bukan hanya terfokus bagaimana pandangan agama-agama terhadap sila pertama, tetapi juga meneliti apa yang menjadi keunikan dari pandangan iman Kristen dibandingkan dengan agama-agama lain dalam memahami sila pertama tersebut.

Agama-agama lain yang dimaksudkan di atas: Islam, Kristen Protestan, Katolik, Hindu, Buddha, Kong $\mathrm{Hu} \mathrm{Cu}$, dan aliran kepercayaan. Dari segi agama ini menunjukkan bahwa Indonesia merupakan masyarakat yang majemuk (Daulay, 2011, p. 94). Sebagai negara yang berpancasila, idealnya kehidupan umat beragama dapat harmonis, namun faktanya implementasi kerukunan umat beragama di Indonesia, sudah tidak lagi mencerminkan nilai-nilai yang terkandung dalam sila pertama Pancasila. Di Indonesia, agama Islam, Kristen, Ahmadiyah atau dengan hubungan agama lain belum mencapai kerukunan yang hakiki dan sampai saat ini pun masih ada saja faktor-faktor pendorong yang hendak memicu ketidakrukunan tersebut (Aritonang, 2014, p. 3-10).

Padahal nilai dari sila pertama adalah perwujudan penghargaan yang setara kepada agama-agama di Indonesia. Tidak ada satu pun agama yang menjadi dasar hukum di negara ini. Dengan digunakannya ideologi Pancasila, maka Indonesia bukan negara agama, melainkan negara Pancasila (Mukhlis, 2016, p. 171-186).

Kalau saja ternyata ada indikasi yang menyatakan bahwa agama itu menciptakan suatu perselisihan antar umat beragama berarti agama tidak lain sebagai virus yang menggerogoti keharmonisan umat beragama. Padahal inti dari pengajaran pada setiap agama bertujuan untuk saling rukun, menghormati, menghargai tanpa memandang perbedaan.

Perlu diketahui bahwa, sila Ketuhanan Yang Maha Esa, tidak mesti harus dipahami menurut akidah (pandangan atau sumber keyakinan) Islam. Namun di dalam Pancasila setiap agama-agama diberikan ruang, untuk memberikan tafsiran terhadap sila pertama Pancasila (Schumann, 2000, p. 82). Tafsiran agama-agama terhadap sila Ketuhanan Yang Maha Esa harus mendukung semangat membangun persatuan bangsa di Indonesia (Sitompul, 2011, p. 230).

Adapun butir-butir Pancasila sila pertama di antaranya sebagai berikut:

(1) Percaya dan Takwa kepada Tuhan Yang Maha Esa sesuai dengan agama dan kepercayaan masing-masing menurut dasar kemanusiaan yang adil dan beradab. (2) Hormat menghormati dan bekerja sama antar pemeluk agama dan penganut-penganut kepercayaan yang berbeda sehingga terbina kerukunan hidup. (3) Saling menghormati kebebasan menjalankan ibadah sesuai dengan agama dan kepercayaannya. (4) Tidak memaksakan suatu agama dan kepercayaan kepada orang lain (Darmaputera, 2002, p. 7-8).

Berdasarkan masalah di atas penulis akan menelaah bagaimana pandangan agamaagama di Indonesia terhadap makna yang terkandung dalam sila pertama Pancasila? Apakah dalam hal ini justru agama mendorong terciptanya ketidakrukunan umat beragama di Indonesia? Bagaimana keunikan pandangan iman Kristen terhadap sila pertama Pancasila dibandingkan dengan agama-agama lain?

\section{METODE}

Penelitian yang dilakukan dalam artikel ini bersifat deskriptif. Metode penelitian ini ditujukan untuk menggambarkan fenomena ketidakrukunan umat beragama yang sudah berlangsung sejak masa sesudah Orde Baru. Untuk menjawab persoalan ketidakrukunan 
umat beragama, penelitian ini menggunakan pendekatan kepustakaan (literatur). Hal ini dimaksudkan untuk menyelidiki bagaimana pandangan dari setiap agama-agama di Indonesia terhadap makna dari sila pertama Pancasila. Setelah menemukan pandangan akan setiap agama-agama tersebut maka penulis dapat menganalisis penyebab ketidakrukuan umat beragama sekaligus memberikan kesimpulan dari penelitian ini.

Dengan demikian melalui penelitian ini khazanah keilmuan setiap pembaca semakin diperkaya mengenai pandangan agama-agama terhadap sila pertama Pancasila yang pada akhirnya pembaca dapat dituntun untuk dapat hidup berdampingan dengan damai tanpa ada niat untuk menyingkirkan kelompok agama lainnya.

\section{HASIL DAN PEMBAHASAN}

Dalam bagian ini akan diulas mengenai pandangan dari setiap masing-masing agamaagama di Indonesia terhadap makna dari sila pertama Pancasila "Ketuhanan Yang Maha Esa" dan pada bagian terakhir secara khusus ada dibahas secara tersendiri bagaimana keunikan iman Kristen terhadap sila pertama Pancasila dibandingkan dengan agama-agama lain.

\section{Pandangan Agama Buddha}

Sejak awal kehadiran agama Buddha datang ke Nusantara sangat ramah, toleran terhadap masyarakat yang ada di Nusantara. Memang di dalam ajaran Sang Buddha pernah mengajarkan tentang pentingnya sikap toleran dan saling menghormati terhadap masyarakat yang berbeda agama dengan mereka. Ajaranajaran mulia tersebut kemudian dituliskan dalam kitab suci Tripitaka (Rashid, 2002, p. 177). Salah satu kisah yang termuat dalam kitab tersebut sebagai berikut:

Pada zaman Buddha, di Nalanda berdiam seorang yang kaya raya dan berpengaruh bernama Upali. Upali adalah penganut agama
Jaina dan gurunya bernama Nigatha Nataputta yang terkenal karena kebijaksanaannya. Pada suatu hari Nigatha Nataputta mengutus Upali muridnya untuk menghadap Sang Buddha untuk mengetahui ajaran tentang hukum karma, karena ada bagian tertentu dari ajaran tentang karmanya berbeda dari ajaran karma Sang Buddha. Pada suatu hari Upali pergi menghadap Sang Buddha. Setelah Upali menyampaikan maksud kedatangannya, Sang Buddha lalu menerimanya dengan baik dan ramah. Selanjutnya terjadilah dialog antara Sang Buddha dengan Upali mengenai doktrin tentang karma. Singkat kisah, akhirnya Upali menerima ajaran mengenai ajaran karma Sang Buddha dan menganut agama Buddha (Diputhera, 1996, p. 73-74).

Pada saat itu, Sang Buddha menerima Upali sebagai siswanya asalkan Upali berjanji bahwa, meskipun Upali sekarang telah menjadi penganut Buddha, tetapi ia harus tetap menghargai dan menghormati bekas agamanya serta tetap memberikan penghormatan bahkan dana kepada bekas gurunya. Sebagai pemimpin Buddha, ia selalu merawat keragaman agama yang ada dilingkungannya dengan terus mengembangkan sikap saling menghormati, setiap orang yang ingin menjalankan ibadah sesuai dengan agama dan kepercayaannya dan juga bekerjasama demi kehidupan bersama (Diputhera, 1996, p. 74).

Dalam masa Kerajaan di India munculnya seorang raja yang terkenal, ia bernama Asoka penguasa Kekaisaran Maurya yang pernah menguasai sebagian besar anak benua India (Afganistan-Bangladesh) dan ia juga seorang penganut agama Buddha. Selama kepemimpinan raja tersebut ia selalu konsisten dalam mengamalkan ajaran cinta kasih Sang Buddha di mana ia memperlakukan masyarakat yang memiliki beragam keyakinan dengan adil tanpa membeda-bedakan. Kesaksian hidup dari raja tersebut kemudian dikenang 
dalam bentuk "prasasti batu Kalinga No. XXII Raja Osaka." Dalam Prasasti itu antara lain ditemukan kalimat berikut: “... janganlah kita hanya menghormati agama sendiri dan mencela agama orang lain tanpa suatu dasar yang kuat. Sebaliknya agama orang lain pun hendaknya dihormati atas dasar-dasar tertentu..." (Yewangoe, 2001, p. 57).

Bagaimana dengan di Indonesia? Di Indonesia terbentuknya wadah musyawarah antar umat beragama yang di dalamnya terdapat WALUBI (Perwakilan Umat Buddha Indonesia), sampai sekarang telah banyak dilakukan usaha yang berkaitan dengan peningkatan kerukunan umat beragama. Usaha-usaha tersebut berupa pernyataan, mengenai imbauan dan seruan yang memperlihatkan kepeduliannya terhadap kerukunan umat beragama dan kesejahteraan umum (Rashid, 2002, p. 116).

Agama Buddha mengajarkan sikap toleran kepada agama lain, hal tersebut dibuktikan dengan dikisahkannya tokoh Upali yang berpindah keyakinan menjadi murid Buddha. Pesan, yang ditekankan oleh Sang Buddha kepada Upali, tetap menghargai dan tidak mencela agama sebelumnya yang dianutnya.

Dalam sejarah kekuasaan kerajaan Raja Osaka juga menerapkan model yang diajarkan oleh Sang Buddha untuk saling menghargai, menghormati dan bersikap adil kepada semua pemeluk agama yang ada di AfganistanBangladesh.

Kemudian, di Indonesia telah dibentuk suatu wadah perkumpulan untuk para pemuka atau pemimpin umat Buddha se-Indonesia atau yang dikenal dengan WALUBI. Organisasi agama WALUBI adalah sebuah wadah (persekutuan) yang berperan untuk peduli melihat masalah-masalah yang tengah dihadapi oleh bangsa ini termasuk upaya dalam membina peningkatan kerukunan umat beragama.

\section{Pandangan Agama Hindu}

Dalam keyakinan Hindu Dharma terbentuknya bangsa Indonesia didorong oleh semboyan satu nusa, satu bangsa serta Bhinneka Tunggal Ika di dalam segala bentuk gerakan bangsa Indonesia. Landasan filosofis tersebut merupakan aplikasi dari nilai agama (Diputhera, 1996, p. 112).

Dalam ajaran Hindu, puncak keTuhanan Yang Maha Esa adalah penyatuan jiwa manusia dengan sumber Yang Maha Kuasa. Penyatuan ini maka termanifestasi dalam bentuk kasih sayang tanpa pamrih. Ketika aku Tuhan ada di dalam diri umat Hindu maka umat Hindu dapat saling menghormati dan mengasihi sesama tanpa pamrih. Dalam hal ini umat Hindu meyakini bahwa nilai saling menghormati dan mengasihi dapat menciptakan kerukunan bersifat universal (Yewangoe, 2001, p. 54).

Agama Hindu mempunyai filosofi yang berbunyi: "Bhina Ika, Tan Hana Dharma Mangrwa." Kalimat ini dicetuskan oleh Mpu Tantular yang memiliki arti bahwa jalan untuk sampai kepada Tuhan berbeda, meskipun berbeda tujuannya sama yakni sampai kepada Tuhan. Filosofi ini hendak menegaskan bahwa tidak ada ajaran agama yang salah dan tidak ada dorongan untuk bersikap membedakan orang berdasarkan latar belakang agama (Yewangoe, 2001, p. 54).

Kerukunan menurut konsep Hindu tertuang dalam Kitab Bhagavad Gita: Ye yatha mam prapadyante tanis tathai va bhajamy aham mama vartma muvartante manusyah partha, sarvasab," yang artinya "dengan jalan bagaimanapun orang-orang memuja-Ku dengan jalan yang sama itu juga Aku memenuhi keinginan mereka. Melalui banyak jalan manusia mengikuti jalan-Ku." Pernyataan di atas menunjukkan bahwa banyak jalan yang bisa ditempuh menuju Tuhan, dan Tuhan memperlakukan sama kepada semua pemeluk 
agama meskipun jalan dan cara beragamanya berbeda (Yewangoe, 2001, p. 55-56).

Ringkasnya, dalam ajaran agama Hindu, dikenal dengan semboyan "walaupun berbedabeda namun satu jua" yang kemudian semboyan tersebut diadopsi secara luas oleh masyarakat, sebagai warisan yang berharga dari nenek moyang bangsa Indonesia. Pengajaran dalam agama Hindu mengajarkan untuk saling mengasihi sesamanya agar dapat terciptanya keharmonisan dalam kehidupan bermasyarakat dan menghargai pengajaran dan ritus keagamaan yang berbeda yang ada di setiap agama, oleh karena setiap agama mempunyai jalannya masing-masing untuk sampai kepada Tuhan.

\section{Pandangan Konghucu}

Sekilas mengenai sejarah keberadaan agama Konghucu di Indonesia. Pada masa Presiden Soeharto agama Konghucu belum mendapatkan pengakuan resmi dari pemerintah sebagai agama. Bagi Soeharto ajaran Konghucu hanya berisikan ajaran mengenai etika dan filsafat. Hal ini membuat, keberadaannya mengalami hambatan untuk berkembang di masa pemerintahan Soeharto. Namun, memasuki masa pemerintahan Presiden Gus Dur, agama Konghucu mulai memperoleh pengakuan (legitimasi) dari pemerintah sebagai agama resmi, bahkan juga menjadi bagian dari kebudayaan yang dipunyai bangsa Indonesia (Huda \& Sari, 2019, p. 1534).

Lantas, bagaimana agama Konghucu memandang sila pertama Pancasila? Sila pertama dipandang sejalan dengan pandangan Nabi Kongzi yang mengajarkan umatnya untuk tidak mengungguli siapa pun. Kitab Si Shu (Su $\left.S_{i}\right)$ mengatakan agar jangan merendahkan umat lain demi martabat dan keluhuran agama Konghucu (Huda \& Sari, 2019, p. 15-34). Agama Konghucu mengajarkan bahwa Tuhan yang memberikan kemerdekaan, oleh sebab itu harus dijaga. Dan karena kemerdekaan tersebut, setiap orang berhak memilih agama yang diinginkannya tanpa tekanan (Huda \& Sari, 2019, p. 15-34).

Senada dengan itu Nabi Kongzi, memberikan pandangan lain bagaimana menyingkapi kemajemukan yang ada di masyarakat. Umat Konghucu berpegang pada sabda dalam Kitab Lunyu 15:40 terkait bagaimana sikap umat Konghucu ketika mengalami perjumpaan dengan agama di luar dari mereka? yang berbunyi, "Bila berlainan jalan suci, jangan berdebat." Dalam hubungan ini, perbedaan bukan untuk dipersoalkan sebab perbedaan jalan suci merupakan realitas yang nyata. Sebab sering kali perselisihan yang terjadi akibat dari manusia itu sendiri yang selalu menilai sesamanya dari perspektif diri mereka tanpa bersedia memahami perspektif orang lain (Pendidikan Agama Kong $\mathrm{Hu} \mathrm{Cu}, 2016$, p. 112).

Semasa hidupnya, Nabi Kongzi memberikan pedoman kepada Zi Zhang yang ketika itu bertanya kepada Nabi Kongzi, "Bagaimanakah sikap yang benar ketika hidup dan berelasi di luar daerahnya? Nabi bersabda:

Perkataanmu hendaklah kau pegang dengan satya dan dapat dipercaya; perbuatanmu hendaklah kau perhatikan sungguhsungguh. Dengan demikian, di daerah Man dan Mo pun, tingkah lakumu dapat diterima. Kalau perkataanmu tidak kau pegang dengan satya dan dapat dipercaya, perbuatanmu tidak kau perhatikan sungguhsungguh, sekalipun di kampung halaman sendiri mungkinkah dapat diterima? Kalau engkau sedang berdiri, hendaklah hal ini kau bayangkan seolah-olah di mukamu, kalau sedang naik kereta bayangkan seolah-seolah hal ini nampak di atas gandaran keretamu. Dengan demikian tingkah lakumu dapat diterima.

Zi Zhang kemudian menuliskan katakata tersebut pada sebuah ikat pinggangnya (Lunyu XV: 6) (Pendidikan Agama Kong Hu 
Cu, 2016, p. 112-113).

Keanekaragaman yang ada di masyarakat itu merupakan sebuah kekuatan dan tidak harus dipertentangkan. Dalam hubungan ini Nabi Kongzi memberikan contoh di mana semasa hidupnya ia menerima murid-murid yang berasal dari latar belakang suku berbedabeda. Selain itu Nabi Kongzi pernah berhasil mengatur pemerintahan dengan baik bahkan dalam jalannya pemerintahan ia tidak menyuruh menggunakan satu sistem dari budaya tertentu saja. Dengan kebijakan ini dapat terlihat bahwa Nabi Kongzi lebih mengutamakan kepentingan orang banyak di atas kepentingan pribadi ataupun kelompok. Ia selalu mengusulkan hal-hal yang baik bagi seluruh masyarakat (Pendidikan Agama Kong $\mathrm{Hu} \mathrm{Cu}, 2016$, p. 113).

Dengan demikian dapat disimpulkan bahwa Nabi Kongzi mengajarkan kepada umatnya dalam memandang perbedaan dalam segi apa pun yang ada di tengah masyarakat, termasuk agama tidak disikapi dengan saling berdebat atau menghakimi satu dengan yang lain tetapi bagaimana umat Konghucu diajak untuk memahami yang berbeda dengan kita dari sudut pandang orang lain. Selain itu ajaran Konghucu mengajarkan kepada umatnya menjaga perkataan dan perbuatan dengan baik, agar keberadaan umatnya dapat diterima di lingkungan mana pun, lalu memandang perbedaan sebagai kekuatan untuk saling melengkapi. Dan yang terakhir mengedepankan kepentingan bersama di atas kepentingan kelompok kecil. Ajaran Nabi Kongzi ini menjadi pedoman bagi umat Konghucu dalam menjalani relasi di tengah masyarakat di Indonesia. Dan ajaran dari Nabi Kongzi tidak bertentangan dengan nilai-nilai sila pertama Pancasila, melainkan umat Konghucu menerima dan mendukung ideologi Pancasila.

\section{Pandangan Katolik}

Sila Ketuhanan Yang Maha Esa oleh umat Katolik dipandang sebagai "titik temu" dan dasar pijak bersama dengan pemeluk agama dan kepercayaan lain dalam menjiwai usaha bersama membangun bangsa dan negara berdasarkan keseluruhan Pancasila dan UUD 1945. Tindakan yang keluar sebagai perilaku publik atau umum, merupakan ungkapan bersama dengan pemeluk agama lain, itulah wujud sejauh menyingkapkan sikap berketuhanan seturut iman menurut agama-agama masing-masing (Hardawiryana, 2001, p. 109).

Umat beragama lain harus terbuka dengan keragaman secara khusus dengan umat Islam sebab banyak hal-hal teologis maupun ajaran moral yang dapat mempersekutukan kedua agama ini. Umat Katolik tidak dapat berbuat lain selain berdialog dan kerja sama. Gambaran tentang cara membangun kerukunan antar umat beriman dan beragama lahir dalam empat macam bentuk kegiatan di antaranya: (1) dialog kehidupan; (2) dialog pengalaman religius; (3) Dialog teologis; dan (4) dialog aksi atau kerja sama. Diharapkan, melalui itu semua terjalin hubungan yang harmonis dan akrab di lingkungan sosialkemasyarakatan (Yewangoe, 2001, p. 53-54).

Berkaitan dengan hal tersebut, KWI (Konferensi Wali Gereja Indonesia), sebagai lembaga yang dipunyai umat Katolik memiliki pedoman dalam statuta tahun 1992. Dalam terang iman Katolik, KWI berdasarkan Pancasila yang berorientasi kepada kehidupan kepada kehidupan bermasyarakat, berbangsa dan bernegara di antaranya sebagai berikut (Hardawiryana, 2001, p. 109-110):

1. Umat Katolik di tengah masyarakat dipanggil menjadi "tanda dan sarana persatuan mesra dengan Allah dan kesatuan seluruh umat manusia"; titik berat usaha mereka: mendekatkan siapa pun kepada Tuhan dan membina persaudaraan di antara manusia, berdasarkan hukum pertama dalam iman Kristen cinta kasih yakni akan Allah dan sesama. 
2. Manusia diciptakan oleh Allah sendiri dan menuju Allah sebagai tujuan akhir hidupnya. Kendati (Barangkali: Justru karena) berbeda suku, bahasa, budaya serta agama mereka, semua sama-sama makhluk ciptaan yang disayangi oleh Allah.

3. Kasih persaudaraan yang dibangun atas dasar keprihatinan bersama demi terwujudnya kemaslahatan hidup di masyarakat.

4. Umat Katolik diharapkan menjunjung tinggi "kebebasan beragama", yang dasarnya ialah martabat manusia sebagai ciptaan Allah. Tanpa kebebasan bersikap menurut suara hati manusia, tidak ada iman itu sendiri.

5. Umat Katolik didorong untuk mengetahui kebaikan dari agama lain, yang "tidak jarang toh memantulkan sinar kebenaran yang menerangi semua orang".

Pandangan dari umat Katolik memandang sila pertama Pancasila dipandang sebagai "titik temu" dari agama-agama yang ada di Indonesia. Umat Katolik lebih bersifat terbuka dan memahami perbedaan yang ada di Indonesia, sebagai karya yang diciptakan Allah. Dalam mempererat hubungan kerukunan umat beragama, umat Katolik melakukan berbagai pendekatan yang kreatif di antaranya: dialog teologis, religius, dialog kehidupan, dan ikut terlibat dengan agama-agama lain, dalam pembangunan bangsa Indonesia.

\section{Pandangan Kristen Protestan}

Gereja sebagai Tubuh Kristus (Rm. 12:4-8; 1 Kor. 12:12-31), artinya keberadaan gereja harus saling peduli dan berbagi dengan orang lain. Sikap tersebut merupakan jalan terbaik untuk melaksanakan kesaksian dengan cara dialog yang menyangkut kehidupan bersama. Hal ini merupakan identitas kekristenan di mana seorang Kristen terpanggil untuk mengasihi Allah, sesama atau tetangga. Tidak boleh dikaburkan (Mat. 22:37-40) (Yewangoe, 2001, p. 49). Dalam hal ini juga didukung dengan sebuah kesaksian Alkitab yang berbicara tentang manusia sebagai citra Allah (Imago Der) yang artinya semua orang dengan latar belakang identitas yang berbeda hendaklah dipandang sebagai saudara. Sebelumnya relasi umat manusia telah dirusak oleh dosa yang kemudian dipulihkan oleh Sang Manusia: Yesus. Di sanalah kita memperoleh landasan kuat bagi persaudaraan umat manusia. Alkitab juga menegaskan bahwa "Allah itu baik bagi semua orang." Hal demikian seharusnya terbangun dalam relasi-relasi antar manusia yang seyogianya diterapkan dalam relasi-relasi intern umat Kristen (Yewangoe, 2001, p. 105).

Sehubungan dengan ini (hubungan dan kerja sama dengan semua umat beragama) juga tercantum di dalam Dokumen Keesaan Gereja yang mengamanatkan:

Sesungguhnya Allah menciptakan manusia menurut gambar dan citra-Nya (Bnd. Kej. 1:26). Allah adalah Allah bangsa-bangsa (Bnd. Maz. 47:9-10). Ia tidak saja mengasihi Israel, tetapi juga Edom, Mesir, dan seterusnya. Yesus Kristus memerintahkan agar kita mengasihi sesama seperti diri kita sendiri (Bnd. Mat. 22:39). Itulah juga hakikat inkarnasi Ilahi di dalam Yesus Kristus yang adalah Manusia bagi orang lain. Atas dasar ini maka kita menjalin relasi dengan sesama tanpa memandang suku, agama, ras, dan golongan (Dokumen Keesaan PGI 2004-2009, p. 68).

Dalam masyarakat yang pluri-agama dan pluri-budaya, umat Kristen diharuskan terlibat aktif mewujudkan Nusantara Baru, dan hal tersebut perlu menumbuhkembangkan sikap persaudaraan sejati melalui sikap dasar kerukunan. Sikap tersebut bukan asal "rukunrukunan" yang dangkal dan terpaksa. Namun, Alkitab mencatat bahwa Yesus mengasihi para murid-Nya ( Yoh. 13:34-35). Oleh karena itu diperlukan "saling-asih, saling-asah, saling- 
asuh." Artinya: saling mengerti dan memedulikan, termasuk saling mengenal keyakinan agama atau kepercayaan masing-masing. Sebab tanpa itu mudah mencuat dugaan, rasa curiga, kesalahpahaman, yang menggerogoti solidaritas yang sesungguhnya. Diperlukan tekad bersama mengikis habis, menanggulangi kendala-kendala itu (Hardawiryana, 2001, p. 17).

Sularso Sopater mengatakan bahwa kerukunan merupakan kesadaran dari hati yang dalam yang didorong oleh keyakinan imani yang dalam, sebagai perwujudan dari iman Kristen. Keyakinan yang demikian ini melihat saudara-saudara yang lain walaupun berbeda agama dan kepercayaan, bukanlah sebagai pesaing atau musuh, tetapi sebagai sesama ciptaan Tuhan yang dengan tujuan agar orang Kristen dapat hidup bekerja sama bagi kebaikan bersama, dan oleh karena itu harus menerima eksistensi agama lain, dan saling mengusahakan kesejahteraan lahir batin, di dalam menjalankan sikap kerukunan di antar umat beragama (Sopater, 2002, p. 17).

Dalam Kitab Suci umat Kristen juga telah ditemukan hal-hal yang mempunyai kaitan tentang kerukunan. Sikap kerukunan tersebut terwujud dalam hubungan dengan Allah dan sesamanya. Hal ini ditunjukkan dalam bagaimana sikap orang-orang yang berbeda agama. Kerukunan itu harus muncul dari hati yang tulus dan itu telah lebih dulu diterapkan di dalam kehidupan Yesus Kristus, sikapnya terhadap banyak orang, untuk saling mengasihi orang lain. Di tengah konflik karena perbedaan paham teologi dan tindakan anarkis sekalipun, umat Kristen juga diajarkan untuk mengampuni (Ef. 4:32) dan tidak membalas perbuatan yang tidak etis untuk dilakukan. Sehingga dengan demikian, menciptakan kerukunan di tengah perbedaan. Jika kerukunan itu dapat tercapai maka kebebasan beragama pun akan dapat diraihnya, begitu juga sebaliknya.

\section{Pandangan Islam Fundamentalis}

Di Indonesia kelompok Islam funda- mentalis menganggap bahwa Islamlah yang bisa menafsir Pancasila dengan baik. Salah satunya ialah sila pertama Pancasila "Ketuhanan Yang Maha Esa." Bagi kalangan Islam fundamentalis 'Tuhan' yang dimaksudkan ialah Allah SWT. Sehingga kalangan Islam fundamentalis meyakini bahwa Islam bukan hanya sekadar agama melainkan juga sistem politik yang diyakini dapat mengatur dan mampu menyelesaikan berbagai persoalan kehidupan di masyarakat. Oleh sebab itu hukum Syariat Islam bagi kalangan Islam fundamentalis perlu mendapatkan legitimasi hukum ke dalam sistem Undang-undang di Indonesia (Aritonang, 2014, p. 64-65).

Selain itu, di kalangan Islam fundamentalis terdapat pandangan yang menolak pluralisme agama bahkan dianggap haram oleh fatwa MUI (Majelis Ulama Indonesia), karena pluralisme menganggap semua ajaran agama sama. Pernyataan tersebut, didasarkan bahwa adanya dalil keagamaan yang digunakan untuk mengharamkan pandangan pluralisme agama antara lain: perihal keyakinan, bahwa Islam adalah agama yang paling benar (Q.S.: Ali Imran [3], 19); agama selain Islam tidak akan diterima Tuhan di hari akhirat nanti (Q.S.: Ali 'Imran [3], 85) (Miswari, 2010, p. 182). Jika dianggap demikian, maka Islam mempunyai keyakinan kuat bahwa Islam adalah agama yang mempunyai kebenaran tertinggi. Keyakinan terlampau tinggi itu membuat Islam fundamentalis menolak pluralisme agama. Padahal pluralisme agama adalah bagian dari karya ciptaan Tuhan. Ketika Islam fundamentalis menolak keberagaman agama yang ada di sekitarnya itu sama dengan menolak karya-Nya.

Berikut ini, merupakan ayat-ayat suci dalam Al-Quran yang menjadikan sebagai titik berangkat dari fundamentalisme dalam Islam:

1. Barang siapa yang tidak memutuskan perkara menurut apa yang diturunkan Allah, mereka orang yang ingkar, zalim, 
dan fasiq (S. Al-Maidah (5): 44-47 (Noer, 1983, p. 112-113).

2. Seorang muslim tanpa menerima dan menyerahkan diri sepenuhnya kepada Allah dan melaksanakan hukumhukum-Nya, maka ia bukanlah mukmin atau muslim secara utuh (QS. AlNisa 4:65) (Abbas, 2005, p. 182).

3. Islam fundamentalis menolak pluralisme agama, dan memiliki klaim kebenaran yang melangit (Abbas, 2005, p. 182). Bagi penulis manusia bisa saja berkeyakinan bahwa agamanya yang paling benar, tetapi yang menjadi salah bila, jika manusia tersebut menghakimi agama di luar keyakinannya.

4. Islam fundamentalis sangat menaruh kebencian terhadap non-muslim oleh karena mereka adalah "musuh” (Qur'an 4:101) (Abbas, 2005, p. 187).

Kelompok Islam fundamentalis di Indonesia menginginkan hukum Islam menjadi dasar pijakan dalam kehidupan masyarakat Indonesia. Keinginan ini timbul karena Islam mengakui bahwa hukum Islam adalah hukum yang benar di hadapan Allah. Keyakinan yang tinggi yang diimani oleh umat Islam tertentu membuat mereka merasa bahwa dengan mengimplementasikan hukum Islam dapat (a) mengatur seluruh kehidupan masyarakat Indonesia, (b) mampu menyelesaikan berbagai persoalan yang tengah dihadapi bangsa ini, dan (c) Hukum Syariat Islam juga menyangkut dengan dunia akhirat. Tetapi sisi negatif dari pemberlakuan Syariat Islam yang pertama adalah menolak pluralisme agama yang membuat orang di luar agamanya dipandang musuh padahal agama itu mengajarkan untuk saling mengasihi dan merangkul. Kedua, kelompok Islam fundamentalis ini hendak menyingkirkan Pancasila sebagai ideologi bangsa Indonesia, dengan rasa kepercayaan diri yang tinggi menganggap bahwa Islam adalah agama, hukum, dan ideologi yang tertinggi dan benar. Konsep yang demikian ini dapat menyebabkan agama di luar Islam tidak mendapat tempat terhormat di negara Indonesia.

\section{Pandangan Islam Radikal}

Pandangan Islam fundamentalis sebagaimana yang telah dijelaskan pada bagian atas berpotensi menghasilkan wajah Islam yang berwatak radikal. Hal ini terlihat dari pertumbuhan kelompok militan atau radikal di era reformasi seperti Laskar Jihad (LJ), Majelis Mujahidin Indonesia (MMI), Jamaah Islamiyah (JI), Front Pembela Islam (FPI), Ikhwanul Muslimin (IM), dan Hizbut Tahrir Indonesia (HT/HTI) adalah fenomena menakutkan dalam kaitan dengan agama di pertukaran milenium (Aritonang, 2020a, p. 9). Penetrasi dari keberadaan kelompok militan/radikal sudah menguasai pengelolaan masjid-masjid di Indonesia (Sitompul, 2011, 227).

Kemudian apa yang dimaksud dengan istilah 'radikal'? Kata 'radikal' dalam arti negatifnya berkonotasi "kekerasan.” Menyelesaikan sesuatu dengan kekerasan, bahkan juga dengan mengorbankan pihak lain. Kalau perilaku radikal menjadi “isme," ini lalu menjadi keyakinan, bahkan ideologi. Bila pengertian ini dipadukan dengan kata "Islam," sontak menampilkan wajah muslim/muslimah yang sanggup melakukan hal-hal yang keras, tegas, dan anti kompromi (Aritonang, 2020b, p. 4667).

Islam radikal terbagi menjadi dua makna, yaitu sebagai wacana dan aksi. Radikal dalam wacana cenderung menghindari kekerasan terbuka dalam upayanya mendirikan negara Islam. Sedangkan dalam level aksi, ada kecenderungan mengambil langkah inkonstitusional yang mensyahkan tindakan kekerasan atau teror dalam upaya mengubah sistem Pancasila. Bahkan pemerintah dapat diperangi (Laisa, 2014, p. 2-18).

Relasi antara organisasi radikal dan 
teroris cukup dekat (Laisa, 2014, p. 2-18). Terkait dengan aksi terorisme:

Dalam sebuah acara yang digelar oleh salah satu Pengurus Wilayah GP Ansor di kawasan Sumatera, Ketua Umum PBNU, KH. Said Aqil Siradj dengan tegas mengatakan bahwa ideologi wahabisme merupakan ancaman yang cukup berbahaya bagi kelangsungan NKRI (Negara Kesatuan Republik Indonesia). Meskipun kaum wahabi bukan termasuk teroris, namun wahabisme telah menyediakan landasan teologis yang cukup kuat bagi munculnya aksi-aksi terorisme kekerasan lainnya (Aritonang, 2019, p. 111-141)

Berdasarkan apa yang penulis simpulkan dari pandangan Rosadi (2008, p. 72-73), ada beberapa hal yang memicu gerakan radikal: beranggapan memiliki pandangan paling benar, menolak keragaman agama, sering melontarkan tuduhan kafir kepada pemeluk agama lain, bahkan menghalalkan kekerasan terhadap pemeluk agama lain.

Menarik untuk disimak, Islam radikal adalah kelompok agama Islam yang selalu mengutip ayat-ayat Al-Quran yang bernada bermusuhan dengan orang lain, tetapi tidak mengangkat ayat-ayat yang bersahabat dengan orang lain (Daulay, 2014, p. 13). Padahal dalam Al-Quran ada ayat yang bernuansa perdamaian seperti (Q.S.: Al-Qashash [28], 77) yang berbunyi demikian:

Dan carilah apa yang telah dianugerahkan Allah kepadamu untuk akhirat dan janganlah kamu melupakan bagiannya di dunia dan berbuat baiklah, sebagaimana Allah telah berbuat baik kepadamu, dan janganlah kamu berbuat kerusakan di bumi. Sesungguhnya Allah tidak menyukai orangorang yang berbuat kerusakan (Misrawi, 2010, p. 298).

Akibatnya, paham keagamaan yang bernuansa kekerasan makin mudah mempe- ngaruhi mereka yang tidak mempunyai paham keagamaan yang dangkal dan sempit. Ironisnya, justru pemahaman keagamaan yang bernuansa kekerasan berkembang subur di tengah masyarakat yang mempunyai pendidikan tinggi (Misrawi, 2010, p. 299).

Islam radikal adalah kelompok agama yang menyetujui tindakan kekerasan. Tindakan kekerasan berlawanan dengan pengajaran AlQuran yang mereka pahami. Tentunya tidak semua penganut Islam menyetujui akan kekerasan yang dilakukan oleh kelompok Islam radikal. Perilaku kekerasan itu ditetapkan sebagai perilaku kriminal karenanya hal tersebut berimbas terhadap hilangnya rasa aman di tengah kehidupan bermasyarakat di Indonesia. Fenomena kekerasan yang mengatasnamakan agama telah menyimpang dari nilai agama maupun nilai yang terkandung dalam Pancasila sila pertama. Hal demikian dapat dikatakan sebagai tindakan melawan konstitusi.

\section{Pandangan Islam Moderat}

Kelompok Islam moderat memang tidak menghendaki adopsi hukum agama (Islam) menjadi hukum nasional, baik diberlakukan di berbagai tempat di Indonesia ataupun keseluruhan. Bahkan sebagian umat Islam itu sendiri ada yang tidak setuju dengan pemberlakuan hukum Syariah tersebut karena banyak ketentuan-ketentuan dalam Syariah dianggap tidak sejalan dengan sistem demokrasi dan nilai toleransi di Indonesia (Abdillah, 2005, p. 4).

Selain itu sila pertama Pancasila "Ketuhanan Yang Esa" dalam pandangan Islam moderat memberikan ruang-ruang bagi setiap agama untuk merumuskan secara teologis makna Ketuhanan berdasarkan pandangan dari tiap agama. Semisal, “... membiarkan orang ber-Trinitas (pada agama Kristen), berdewa banyak (pada agama Hindu) atau tidak membicarakan tuhan sama sekali (pada agama Buddha)" (Hikmawati \& Pitana, 2018, 
p. 91; lih. Noer, 1983, p. 113-114).

Pandangan Dr. Nurcholish Madjid (pelopor pembaruan pemikiran Islam) mengatakan bahwa di dalam Al-Quran ada ayat yang berbunyi mengenai pluralisme yang menyatakan:

1. Manusia diciptakan berbangsa-bangsa dan bersuku-suku agar mereka saling menghargai (QS. Al. Hujarat (43):13).

2. Perbedaan tidak perlu digusarkan dalam cara hidup dan hendaknya dipakai sebagai tolak ukur berbuat kebaikan, dan bahwa Tuhanlah yang akan menerangkan mengapa manusia berbeda-beda, ketika kembali kepadaNya (QS. Al-Baqarah (2): 256) (Ridwan, 2002, p. 129)

Hal yang senada juga dikemukakan oleh Dr. Syekh Yusuf al-Qaradhawi dengan menyebutkan empat faktor yang melahirkan sikap toleransi Islam terhadap non-Muslim:

1. Keyakinan terhadap kemuliaan manusia, apa pun agamanya, kebangsaan dan kesukuannya. Kemuliaan ini mengimplikasikan hak untuk dihormati.

2. Keyakinan bahwa perbedaan manusia dalam agama dan keyakinan merupakan realitas (ontologis) yang dikehendaki oleh Allah SWT yang telah memberi mereka kebebasan untuk memilih iman atau kufur (tidak beriman kepada Allah dan rasulnya). Oleh karena tidak dibenarkan memaksa mereka untuk Islam (Q.S. AlBaqarah [2]. 256).

3. Seorang Muslim tidak dituntut untuk mengadili kekafiran orang kafir atau menghukum kesesatan orang sesat. Allah SWT lah yang akan mengadili mereka di hari perhitungan kelak. (alHajj: 69, asy-Syuuraa: 15). Dengan demikian hati seorang Muslim menjadi tenang, tidak perlu terjadi konflik batin antar kewajiban berbuat baik dan adil kepada mereka (al-Mumtahanah: 8) dan dalam waktu yang sama harus berpegang teguh pada kebenaran keyakinannya sendiri.

4. Keyakinan bahwa Allah SWT memerintahkan untuk berbuat adil dan mengajak kepada budi pekerti mulia meskipun kepada orang musyrik (atTaubah:6) (Salim, 2013, p. 214-215).

Bagi kalangan Islam moderat, Pancasila dipandang secara akidah maupun syariah bersifat islami karena beberapa alasan sebagai berikut (Syaiful Arif, 2016, p. 240-266):

1. Sila Ketuhanan Yang Maha Esa menandai nilai paling fundamental dari Islam, yakni tauhid, sebagaimana ayat 1 surah al-Ihlash: Qul Huwa Allobu Abad (Katakanlah bahwa Allah itu Esa). Dengan posisi sila tauhid sebagai sila pertama yang mendasari semua sila Pancasila, maka dasar negara ini secara akidah bersifat tauhid.

2. Dasar ketuhanan menjadikan konstitusi, UU dan kebijakan negara tidak bertentangan dengan Syariat Islam. Dengan demikian, Pancasila yang bertauhid itu tidak melarang dan menghalangi umat Islam dan umat beragama lainnya untuk melaksanakan syariah serta aturan agama-agama di Indonesia.

3. Keempat sila di bawah sila ketuhanan selaras dengan tujuan-tujuan syariah (maqashid al-syariab). Tujuan tersebut merujuk pada perlindungan atas lima hak dasar (al-kulliyat al-khamsah) manusia: menjaga hidup (bifdz, al-nafs), menjaga agama (bifdz al-din), menjaga akal (bifdz al-'aq), menjaga harta (bifdz. al-maal) dan menjaga kehormatan (bifdz. al-ird). Penjagaan dan perlindungan atas hak dasar manusia ini selaras 
dengan nilai kemanusiaan, persatuan, kerakyatan dan keadilan sosial. Artinya, ketika ujung sila Pancasila ialah keadilan sosial, hal ini sama dengan tujuan syariah yang merujuk pada kemaslahatan (al-mashlahat), sebagaimana kaidah hukum Islam (fiqh) menyatakan, haistumakanat al-mashlabah fatsamma syar'u Allah wa haistuma kana syar'u Allah fatsamma al-mashlahah (Di mana ada maslahat, di situ ada syariat. Di mana ada syariat, di situ ada maslahat). Kemaslahatan inilah yang dalam bahasa Pancasila disebut keadilan sosial, dan dalam bahasa (filsafat) politik disebut res publica (kebaikan bersama) yang menjadi dasar bagi sistem pemerintahan republik.

4. NKRI telah mendapatkan pengesahan keagamaan sebagai bagian dari sistem politik yang islami. Hal ini dilakukan oleh warga pesantren dan organisasi Islam moderat seperti Nahdlatul Ulama (NU), Dengan sikap pengesahan ini, NKRI syah secara syar'i, sehingga tidak ada alasan lagi untuk menolaknya atas nama Islam.

Sebagai organisasi keagamaan umat Islam terbesar di Indonesia maupun dunia NU menganut kuat madzhab Syafi'i. Farouq Abu Zaid dalam bukunya, Hukum Islam antara Tradisional dan Modernis, menyebutkan Syafi' sebagai imam kaum moderat. Watak moderat itu disebabkan oleh latar belakang Syafi'i (767820). Dia sendiri yang mengembangkan ajarannya semula di Mekah dan di Madinah, kemudian di Baghdad, dan terakhir di Mesir sehingga ajaran Syafii berkembang sesuai dengan masyarakat sekitarnya (Sitompul, 2010, p. 58).

Dalam pandangan Madzhab Syafi'i bila perlu terbuka menerima suatu kebiasaan yang telah berlaku sebelumnya berlandaskan sebuah hadist yang berbunyi: "apa yang dianggap oleh orang-orang Islam itu baik, maka ia di sisi Allah juga baik". Karena itu dengan menegaskan diri sebagai penganut madzhab Syafi' "dimungkinkan adanya pilihan untuk menyesuaikan dengan keadaan kehidupan yang nyata" (Sitompul, 2010, p. 58)

Sesuai dengan pilihannya itu maka NU mampu akrab dengan kultur Indonesia, dan hal itu mempunyai dasar yang kuat dalam tradisi Islam (Sitompul, 2010, p. 59).

Dengan ini dapat dipahami bahwa pandangan Islam moderat mempunyai pandangan terbuka dengan melihat adanya pluralisme agama di Indonesia. Islam moderat tidak menolak pluralisme agama melainkan melihat pluralisme agama sebagai kekayaan yang dimiliki oleh bangsa Indonesia dan melihat juga sebagai karya ciptaan Tuhan Yang Maha Esa.

Islam moderat membaca, memahami dan menginterpretasi teks-teks Al-Quran secara utuh dan juga menekankan penafsiran yang humanis. Pendekatan yang digunakan untuk memahami teks-teks Al-Quran melalui pendekatan kontekstual. Keistimewaan yang ada pada Islam moderat di Indonesia adalah tidak mudah menghakimi agama di luar Islam sebagai kafir. Oleh karena di mata Tuhan manusia sama derajatnya tidak ada yang lebih unggul ataupun rendah dikarenakan agama yang dianutnya, penghakiman manusia atas keyakinan yang dianut merupakan hak prerogatif Tuhan bukan manusia. Tidak ada unsur paksaan bagi yang non-Muslim untuk memeluk Islam, selain itu Pancasila di mata Islam moderat sangat islami bahkan nilai-nilai syariat Islam terkandung semua dalam Pancasila.

Islam moderat melihat efek negatif yang ditimbulkan jika hukum syariat diterapkan di Indonesia, yaitu agama-agama lainnya mengalami diskriminasi. Islam moderat bukan kelompok agama yang anti pluralisme agama, melainkan paradigma Islam moderat lebih menekankan pemeliharaan terhadap kebera- 
gaman agama sebagai identitas bangsa Indonesia.

Kemudian bagaimana pandangan Islam moderat terhadap perpindahan agama? Sebagian dari umat Islam di Indonesia merasa tidak nyaman jika hukum syariat diberlakukan bagi umat Islam yang "berpindah agama" karena itu dikategorikan "perbuatan murtad" (Daulay, 2014, p. 17). Chandra Muzaffar (pemikir Islam) mengatakan hadist yang digunakan teolog dalam hubungan dengan hukuman mati sedikit banyak telah tercampur dalam kitab-kitab hadist yang konteksnya adalah kasus kriminal di antaranya: pemberontakan dan perampokan. Kasus "orangorang murtad" yang dibunuh di masa Nabi atau beberapa saat sesudah era Nabi adalah mereka kaum Quraisy menganut agama paganisme/penyembahan berhala yang memerangi umat Islam yang ketika itu merupakan komunitas agama yang kecil dan lemah. Jadi apabila di tengah situasi peperangan ditemukan adanya umat Islam yang murtad dan memilih agama yang dianut oleh kaum Quraisy, hal ini dianggap akan membahayakan kekuatan perang bagi umat Islam. Sehingga diputuskan hukum mati bagi yang murtad agar tidak menjadi musuh dalam selimut. Hukuman mati dalam kasus ini adalah upaya bela diri oleh karena alasan situasional (Muzaffar, 2001, p. 259).

Dalam konteks bangsa Indonesia yang mayoritas muslim, namun berdampingan pula dengan penganut agama lainnya sebagai warga negara, maka tidak mudah bila hukum yang diberlakukan itu hukum Islam, lebih-lebih dalam hukum publik terutama terkait dengan sanksi hukum riddah (murtad). Oleh karena itu sanksi terhadap hukum riddah tidak dapat dibenarkan di Indonesia mengapa demikian?

1. Al-Quran tidak menyebutkan adanya penghukuman riddah. Sebab hukuman bagi riddah diserahkan kepada Tuhan pada hari kiamat kelak, dan bukan di dunia sekarang. Al-Quran tidak menetapkan hukuman apa pun bagi riddah, hukuman mati seperti tersebut dalam sunnah melanggar hak asasi kebebasan beragama. Jika perbuatan riddah tidak menimbulkan kerusakan dalam masyarakat, maka tidak perlu ada hukuman apa pun.

2. Pada kasus riddah, di mana kebebasan hak semua bangsa untuk menentukan pilihan beragama, (memiliki) landasannya dalam al-Qur'an, maka pemaksaan untuk menganut agama tertentu dengan berbagai cara dan menjatuhkan hukuman mati atasnya dengan sendirinya dianggap tidak dapat diberlakukan.

3. Hasan Ibrâhim Hasan dan Muhammad Fathî 'Utsmân mengatakan bahwa hukuman riddah lebih bersifat politis ketimbang agama. Di sini lagi-lagi kita melihat bahwa alasan membunuh pelaku riddah bukan al-Qur`an, tetapi politis dan sosiologis.

4. Sanksi terhadap perpindahan agama dapat menyebabkan disintegrasi bangsa dan konflik antar umat beragama dalam wilayah negara kesatuan Republik Indonesia, sehingga menanggalkan ketentuan hukuman mati bagi pelaku riddah ini menjadi suatu keniscayaan (Syafe'i, 2016, p. 160-191).

Bagaimanapun sanksi hukuman mati terhadap yang murtad tidak dapat dibenarkan dalam Al-Quran (Muzaffar, 2001, p. 259). Dengan ini tidak ada seorang pun termasuk juga negara yang memiliki otoritas untuk memaksa seseorang untuk keluar atau masuk ke dalam agama lain.

Pandangan Islam moderat lebih menekankan hak individu di dalam menentukan keyakinannya sesuai dengan nilai dari Pancasila sila pertama. Perpindahan agama dari Islam ke agama lain bukanlah perbuatan kriminal. 
Manusia atau kelompok yang mengatasnamakan agama tidak berhak untuk memberi dan melaksanakan hukuman mati bagi yang murtad. Islam moderat dalam pengamatannya terhadap orang yang berpindah keyakinan itu sebagai hak dari menjalankan kebebasan beragama. Dalam hal ini pun pemerintah dan ormas agama lainnya tidak mempunyai hak untuk memaksakan orang lain untuk memeluk agama tertentu.

\section{Keunikan Iman Kristen dalam Memahami Sila Pertama Pancasila}

Konsep mengenai Ketuhanan Yang Maha Esa juga ada di dalam Alkitab sehingga bagi umat Kristen, sila Ketuhanan Yang Maha Esa bukan merupakan sesuatu yang harus dipermasalahkan. Umat Kristen menerimanya sebagai anugerah Tuhan yang diberikan kepada bangsa Indonesia melalui para pendiri bangsa ini demi kelangsungan hidup berbangsa, bernegara dan beragama (Sumarno, 2020, p. 237-266).

Iman Kristen meyakini bahwa hanya ada satu Allah dan tidak ada yang lain. Dia adalah satu-satunya pencipta alam semesta dan segala isinya. Dialah yang memelihara dan menganugerahkan kemerdekaan kepada negara dan bangsa Indonesia. Bukan hanya kemerdekaan saja, Roh Kudus juga yang mengilahimi para pendiri bangsa (founding fathers) sehingga lahirnya Pancasila (Sumarno, 2020, p. 237266).

Konsepsi Ketuhanan Yang Maha Esa di dalam Alkitab memang berbeda dengan yang dipahami oleh agama-agama lain yang ada di Indonesia. Istilah "esa" yang dipakai di dalam Alkitab bukan satu dalam pengertian "satu mutlak," tetapi satu dalam pengertian "kesatuan dari penyatuan" Bapa, Anak dan Roh Kudus (Sumarno, 2020, p. 237-266).

Dalam teologi inkarnasi Allah hadir bagi semua orang. Hal ini menandakan bahwa Allah Trinitas menjalin relasi terbuka dan saling merangkul dengan semua ciptaannya secara khusus umat manusia tanpa kecuali. Ini artinya umat Kristen harusnya memperlihatkan sikap keterbukaan terhadap kehadiran orang-orang yang berbeda agama dengan orang Kristen dan meyakini mereka juga adalah bagian dari keluarga Allah.

Kemudian kita bertanya mengenai mengapa sila pertama "Ketuhanan Yang Maha Esa" diletakkan pada urutan pertama yang mempunyai implikasi yang menentukan bagi keseluruhan makna dari setiap sila dalam Pancasila? Eka Darmaputera (teolog dan rohaniwan GKI) memiliki argumentasi bahwa hal tersebut memiliki alasan teologis:

Dasar Ketuhanan Yang Maha Esa menjadi dasar yang memimpin cita-cita bangsa Indonesia. Jikalau sewaktu-waktu bangsa ini mengalami kesasaran dalam perjalanannya akan ada senantiasa desakan Roh Kudus yang membimbing ke jalan yang benar Sebab Ketuhanan Yang Maha Esa tidak hanya sekadar hormat-menghormati agama masing-masing tetapi juga menjadi dasar untuk memimpin perjalanan bangsa dan negara ini ke jalan kebenaran, keadilan, kebaikan, kejujuran, persaudaraan dan lainlain bagi kepentingan masyarakat Indonesia (Darmaputera, 1987, p. 107-108).

Pertanyaan berikutnya apa yang menjadi keunikan dari iman Kristen dalam menciptakan sikap saling menghormati, dan memperkuat persaudaraan jika dibandingkan dengan agama-agama lainnya? Iman Kristen mendorong untuk mengaplikasikan dengan didasarkan keyakinan bahwa nilai-nilai tersebut sesungguhnya tidak berasal dari budaya maupun proses berpikir manusia terhadap realitas sosial maupun kebudayaan melainkan nilai-nilai tersebut ditanamkan Tuhan melalui Kristus dan kemudian diamalkan oleh orang yang beriman (Nurcholish \& Dja'far, 2015, p. 122). Itu artinya pandangan iman Kristen meyakini bahwa sila pertama Pancasila terkandung nilai-nilai Firman Allah. 
Pertanyaan terakhir, apa yang membedakan ajaran iman Kristen dengan aliran agama bercorak fundamentalis dan radikal yang sama-sama hidup berdampingan di bumi Pancasila? Pertama, Kitab Suci umat Kristen tidak pernah memuat bahwa Tuhan Yesus memerintahkan untuk mendirikan sebuah sistem politik berbasis Kristen. Sebab tujuan dari kekristenan ialah menghadirkan nilai-nilai Kerajaan Allah. Sedangkan bagi agama bercorak fundmentalis dan radikal, agama memiliki agenda politik (kekuasaan politik) untuk mendirikan negara dengan menjadikan hukum agama sebagai dasar. Kedua, iman Kristen mengajarkan umatnya untuk tidak membeda-bedakan orang berdasarkan agama, suku dan lain-lain apalagi melakukan tindakan kekerasan dengan mengatasnamakan agama terhadap orang yang berbeda dengannya, melainkan iman Kristen mengajak umat untuk saling mengasihi dan menghormati terhadap agama lain. Sedangkan agama fundamentalis dan yang berwatak radikal menciptakan sikap beragama yang eksklusif, keras, dan intoleran terhadap perbedaan.

Dengan demikian di tengah derasnya arus gerakan keagamaan yang berwatak fundamentalis radikal di Indonesia, umat Kristen yang juga merupakan warga negara Indonesia, terpanggil untuk menghidupkan gagasan nasionalisme baik di dalam (internal) gereja maupun di ruang publik (eksternal) dengan maksud tujuan yang mulia, yaitu meskipun berbeda dalam agama, umat Kristen memandang umat beragama lain sebagai saudara sebangsa dan setanah air, yakni keluarga besar bangsa Indonesia. Jika hal demikian dihidupkan secara lahir dan batin ini menjadi sebuah bentuk perlawanan dari arus

\section{DAFTAR RUJUKAN}

Abbas, G. (2005). Telaah Teks dan Konteks Islam di Indonesia: Studi Kasus Aceh. In I. Suherlan (Ed.) Formalisasi Syariat Islam di Indonesia Sebuah Pergulatan yang gerakan anti pluralisme agama di Indonesia.

\section{KESIMPULAN}

Berdasarkan ulasan yang sudah dijelaskan di atas penulis menyimpulkan bahwa pada dasarnya setiap agama baik Islam, Katolik, Kristen Protestan, Hindu, Buddha dan Konghucu, mengajak pengikutnya untuk berpartisipasi dalam menciptakan suasana damai lahir batin, tanpa harus menimbulkan konflik di tengah keragaman agama di masyarakat. Keragaman agama merupakan sebuah ketetapan Tuhan bagi bangsa Indonesia yang mesti dijaga dan dirawat dan itulah letak kekuatan dan keunikan dari bangsa Indonesia yang sudah sepatutnya disyukuri. Namun yang memicu terjadi konflik relasi umat beragama kesalahannya bukan terletak pada agamanya melainkan oleh karena pemahaman agama (teologi) yang dangkal dan interpretasi terhadap teks suci secara keliru yang ditafsirkan sesuai dengan keinginan kelompok agamanya, yang pada akhirnya bermetamorfosis menjadi watak beragama yang fundamentalis dan radikal. Watak beragama yang demikian hanya akan merusak budaya toleransi dan kerukunan yang sudah diwariskan oleh para pendahulu bangsa Indonesia.

Di samping itu dalam terang iman Kristen, Pancasila dipercayai merupakan 'karya Roh Kudus' dari Tuhan Allah kepada bangsa Indonesia yang mengilhami para pendiri bangsa (founding fathers) yang melahirkan Pancasila. Secara khusus sila pertama Pancasila dapat dijadikan pedoman hidup bersama dalam masyarakat majemuk demi terwujudnya kerukunan umat beragama di bumi Nusantara.

Tak Pernah Tuntas, Formalisasi Syariat Islam (pp. 182-187). Renaisan.

Abdillah, M. (2005). Wacana Formalisasi Syariat Islam. In I. Suherlan (Ed.) Formalisasi Syariat Islam di Indonesia Sebuah 
Pergulatan yang Tak Pernab Tuntas (pp. 17). Renaisan.

Arif, S. (2016). Islam, Radikalisme, Deradikalisis, dan Pancasila, Societas Dei, 3(3): 240-266

Aritonang, A. (2014). Signifikansi sila-1 Pancasila bagi Umat Beragama [Skripsi, STT Cipanas]

Aritonang, A. (2019). Kekristenan dan Nasionalisme di Indonesia. Jurnal Amanat Agung, 15(1): 111-141. https:// ojs.sttaa.ac.id/index.php/JAA/article/ view $/ 344 / 332$

Aritonang, A. (2020a). Andreas A. Yewangoe dan Oikoumene Kontribusi pemikiran Andreas A. Yewangoe bagi Kekristenan dan Kemajemukan Agama di Indonesia [Tesis, ST'T Cipanas]

Aritonang, A. (2020b). Bangkitnya Islam Radikal dan Nasionalisme: Studi tentang Gerakan Islam Wahabi. Jurnal Efata, 6(2): 46-67. https:// ejournal.sttiman.ac.id/ index.php/efata/article/view/29/20

Darmaputera, E. (1987). Pancasila Identitas Dan Modernitas: Tinjauan Etis dan Budaya. BPK Gunung Mulia.

Darmaputera, E. (2002). Berbagai Dimensi Kerukunan Hidup Beragama. In W. Sairin (Ed.) Kerukunan Umat Beragama Pilar Utama Kerukunan Beragama. BPK Gunung Mulia.

Daulay, R. M. (2014). Kristenisasi dan Islamisasi Umat Kristen dan Kebangkitan Islam Politik Pada Era Reformasi di Indonesia. BPK Gunung Mulia.

Daulay, R. M.. (2011). Kekristenan dan Politik. Jakarta: Waskita.

Diputhera, I G. N. O. (1996). Toleransi dan Kebebasan Beragama Telah Menjadi Pandangan Hidup Bangsa Indonesia. In T. B. Simatupang (Ed.) Peranan Agamaagama dan Kepercayaan Terbadap Tuban Yang Maha Esa dalam Negara Pancasila Yang Membangun (pp. 69-88): BPK Gunung Mulia.

Dokumen Keesaan Gereja Persekutuan
Gereja-gereja di Indonesia (DKG-PGI) 2004-2009. PGI.

Laisa, M. (2014). Islam dan Radikalisme. Jurnal Islamuna, 1(1): 2-18

Hardawiryana, R. (2001). Dialog Umat Kristiani dengan Umat Pluri-Agama/Kepercayaan di Nusantara. Kanisius.

Hikmawati, H. \& Pitana, T. S. (2018). Oneness of God's Concept from Rimba Watualang. Ibda: Jurnal Kajian Islam Dan Budaya, 16(1), 85-103. https://doi.org/ 10.24090/IBDA.V16I1.1392

Huda, M. T. \& Sari, R. S. I. Toleransi dan Praktiknya dalam Pandangan Agama Khonghucu, Jurnal Studi Agama, 4(1): 1534.

Misrawi, Z. (2010). Al-Qur'an Kitab Tolerans Tafsir Tematik Rabmatan Lil Alamin. Pustaka Oasis.

Mukhlis, F. H. (2016). Teologi Pancasila: Teologi Kerukunan Umat Beragama. Fikrah: Jurnal Aqidah dan Studi Keagamaan, 4(2): 171-186.

Muzaffar, C. (2001). Universalisme dalam Islam. In C. Kurzman (Ed.) Wacana Islam Liberal: Pemikiran Islam Kontemporer tentang Isu-isu Global, ed. Charles Kurzman (pp. 238-249). Parmadina.

Noer, D. (1983). Islam, Pancasila dan Asas Tunggal Pancasila. Yayasan Perkhidmatan.

Nurcholish, A \& Dja'far, A. M. (2015). Agama Cinta: Menyelami Samudra Cinta AgamaAgama. Elex Media Komputindo.

Pendidikan Agama Kong $\mathrm{Hu} \mathrm{Cu}$ di Pendidikan Tinggi. (2016). Direktorat Jenderal Pembelajaran dan Kemahasiswaan Riset Teknologi dan Pendidikan Tinggi.

Rashid, S. M. (2002). Kerukunan Hidup Beragama Menengok Masa Lampau dan Menatap Masa Depan Menurut Persepsi Buddhis. In W. Sairin (Ed.) Kerukunan Umat Beragama Pilar Utama Kerukunan Berbangsa: Butir-Butir Pemikiran (pp. 155120). BPK Gunung Mulia.

Ridwan, N. K. (2002). Pluralisme Borjuis Kritik 
atas Nalar Pluralisme Cak Nur. Galang Press.

Rosadi, A. (2008). Hitam Putib Front Pembela Islam: Mengungkapkan Rabasia-rahasia Mencengangkan Ormas Keagamaan Paling Kontroversial. Nun Publisher.

Salim, F. (2013). Tafsir Sesat: 58 Essai Kritis Wacana Islam di Indonesia. Gema Insani.

Schumann, O. (2000). Kehidupan Bersama Umat Kristiani dan Umat Muslim di Indonesia Pada Masa Depan. In Tim Balitbang PGI (Ed.) Meretas Jalan Teologi Agama-agama di Indonesia (pp. 73-99). BPK Gunung Mulia.

Sitompul, E. (2010). NU dan Pancasila: Sejarah dan Peranan NU dalam Perjuangan Umat Islam di Indonesia dalam Rangka Penerimaan
Pancasila sebagai Satu-satunya Asas. LkiS.

Sopater, S. (2002). Agama dan Negara dalam Konteks Kerukunan Pemeluk. In W. Sairin (Ed.) Kerukunan Umat Beragama Pilar Utama Kerukunan Berbangsa (pp. 7681). BPK Gunung Mulia.

Sumarno (2020). Pemahaman Sila Ketuhanan Yang Maha Esa Menurut Iman Kristen (Bagian 2). Jurnal Arrabona, 2(2): 237266.

Syafe'i, Z. (2016). Kontekstualisasi Hukum Islam Tentang Konversi Agama (Riddah) di Indonesia. Jurnal ALQALAM, 33(1): 160-191.

Yewangoe, A. (2001). Agama-Agama Dan Kerukunan. BPK Gunung Mulia. 